\title{
The reliability of long - term energy forecasts
}

\section{Introduction}

The development of mankind has been inextricably linked with the development of energy sources. The economic, scientific and cultural progress of the world has depended on our ability to use them. Energy scarcity, its high price or disruptions in energy supplies lead to stagnation in the development of societies with all its negative implications, such as growing unemployment, decline in living standards, armed conflicts or expansion of poverty levels. Not long ago, energy sources were treated as inexhaustible resources. Then, numerous world economic and political crises made the public aware of the importance of energy issues.

An energy crisis is not only about energy imbalance. Increased energy consumption is accompanied by continuous environmental degradation resulting in irreversible adverse changes in the natural environment, destruction of the cultural heritage of nations and hazards to human life.

The Limits to Growth (Meadows et al. 1972), which is an overall result of the works on the first Club of Rome, should be recognised as the beginning of the development in forecasting methodology.

* Ph.D. Eng., AGH University of Science and Technology, Faculty of Non-Ferrous Metals, Department of Metal Working and Physical Metallurgy of Non-Ferrous Metals, Krakow, Poland; e-mail: bbor@agh.edu.pl

** Professor, AGH University of Science and Technology, Faculty of Energy and Fuels, Department of Fundamental Research in Energy Engineering, Krakow, Poland.

*** Professor, AGH University of Science and Technology, Faculty of Energy and Fuels, Department of Thermal and Fluid Flow Machines, Krakow, Poland. 
The authors of Limits to Growth adopted and modelled a set of variables, such as: world population growth, capital resources, environmental degradation rate, necessary increase in food production, growth in national domestic product and living standards, poverty reduction, increased consumption of energy resources. Their starting points were quite arbitrarily adopted mathematical relationships between the above factors. The shortcomings of such forecasting, which resulted in wrong predictions, were due to, inter alia, unrealistic growth assumptions, lack of correlation between GDP, on the one hand, and living standards and quality of life, on the other, as well as the impact of science and technology on the intensity of economic growth. Within one year from the release of the Club of Rome Report, forecasting methodology developed significantly. For example, the model included in the Club of Rome Report consisted of 480 equations while in the next work, i.e. Humanity at the Crossroads, it was expanded to more than 100,000 equations containing thousands of selectable constants affected by errors (Kopecki 1976). Further development in predictive modelling consisted in the division of the world into regions with varying degrees of economic development (10 regions) and further expansion of modelling correlations (see: Limits to Growth, The 30-Year update (Meadows et al. 2004)). The above created a need to introduce further selectable constants with unspecified error values. Another source of error was the discretionary extrapolation of different correlations.

The above elements of uncertainty should be seen as a source of discrepancies of various proposed models and significant deviations from reality.

The increase in energy demand is primarily forced by population growth, the pace of economic growth, and natural tendency to improve living conditions. The obvious trend for rapid development in poor countries threatened by the poverty trap should also be taken into account. According to the well-documented data, the world's population is expected to exceed eight billion people around 2030. The above means that within the next forty or fifty years, mankind's achievements will have to match the developments attained in the entire history of our civilization. The calls for return to nature in the sense of giving up all the benefits of development, sound utopian and very naive. If it so difficult to arrive to an agreement on the abandonment of weapons or respecting human rights, it is quite unlikely that humanity will abandon the development offered by scientific progress. The general approach to challenges faced by energy forecasting (which is the topic of this paper) is illustrated in Fig. 1.

The paper focuses, in particular, on the GDP $\leftrightarrow$ primary energy demand relationships.

Development forecasts for different areas are an essential component in the planning of civilisation development undertaken by our societies. It is hard to imagine the decision making process of government institutions without using any predictions about the future. The question is, however, how far can such predictions extend into the future to stay reliable. $\mathrm{Cu}-$ rrently, the forecasts that determine the directions in the development of energy systems play an important role in ensuring the economic and political sovereignty of individual countries. This is also directly related to the investment objectives and decisions. Recently, mainly due to the global economic crisis as well as severe and intensifying political conflicts, in addition 


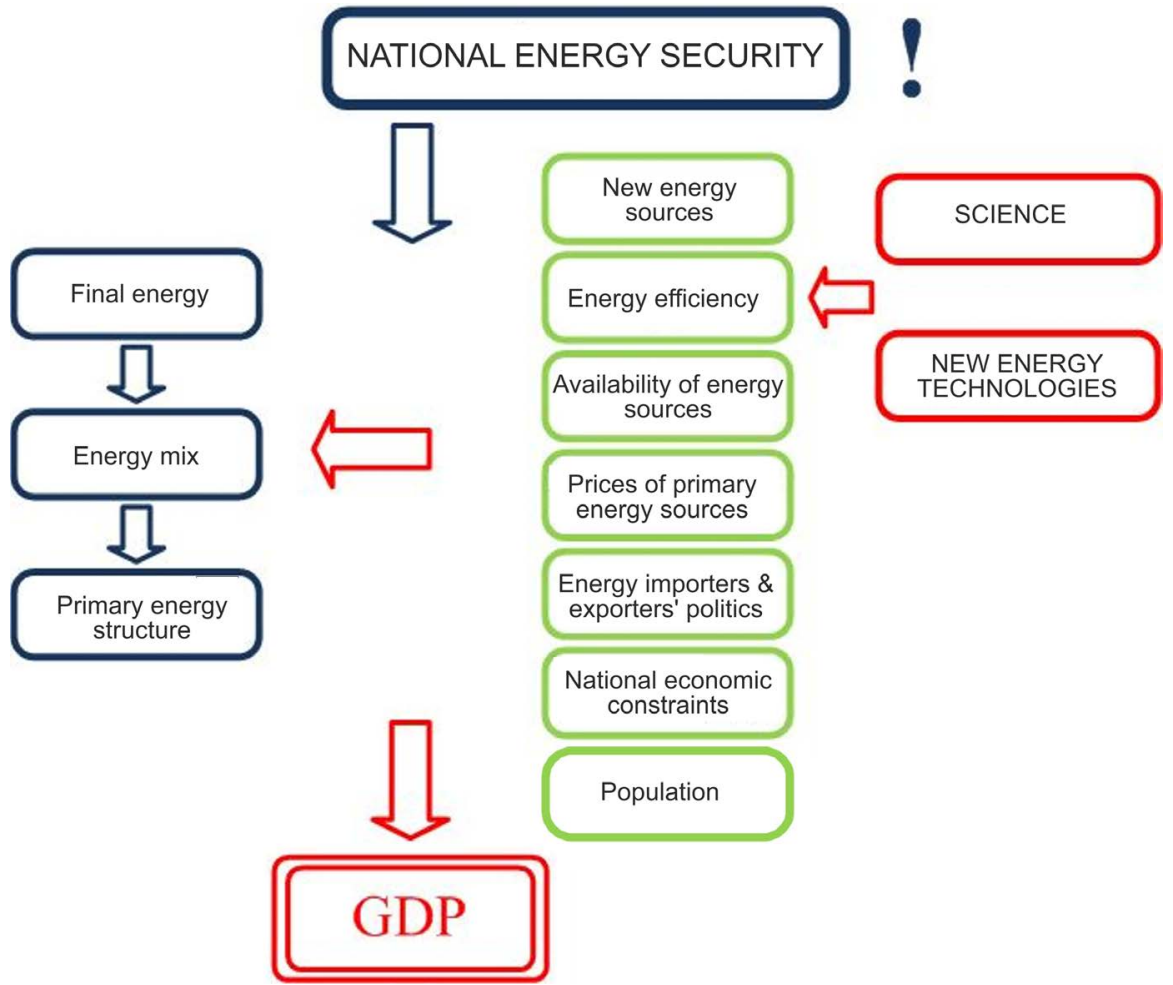

Fig. 1. Energy Forecasting Procedure Components (GDP - Gross Domestic Product) (own research)

Rys. 1. Składowe procedury prognozowania energetycznego (PKB - Produkt Krajowy Brutto) (opracowanie własne)

to the obvious and traditionally included factors causing a rise in energy demand (in various forms), the challenge that emerged in all its very pointed terms, has been the issue of ensuring energy security at national levels.

Additionally essential restrictions in $\mathrm{CO}_{2}$ emission from the power industry have induced coal to be replaced by natural gas and oil (Frączek et al. 2013a, b; Szurlej 2013). Also, the increase of the import of natural gas was not substantiated.

It is definitely a new and important paradigm in energy forecasting which sets new development goals. The traditional approach involves quite an obvious correlation between the GNP (Gross National Product) levels and the demand for primary energy. This GNP vs Primary Energy Consumption correlation for the United States in 1950-1975 is presented as an example in Fig. 2.

Unfortunately, any kind of prediction as much as any extrapolation, is always fraught with errors. In many cases, the error values are so significant that the predictions become meaningless. The price of primary energy is one of the most important value factors used to define the expected increase in its demand. And the unpredictable price changes are a so- 


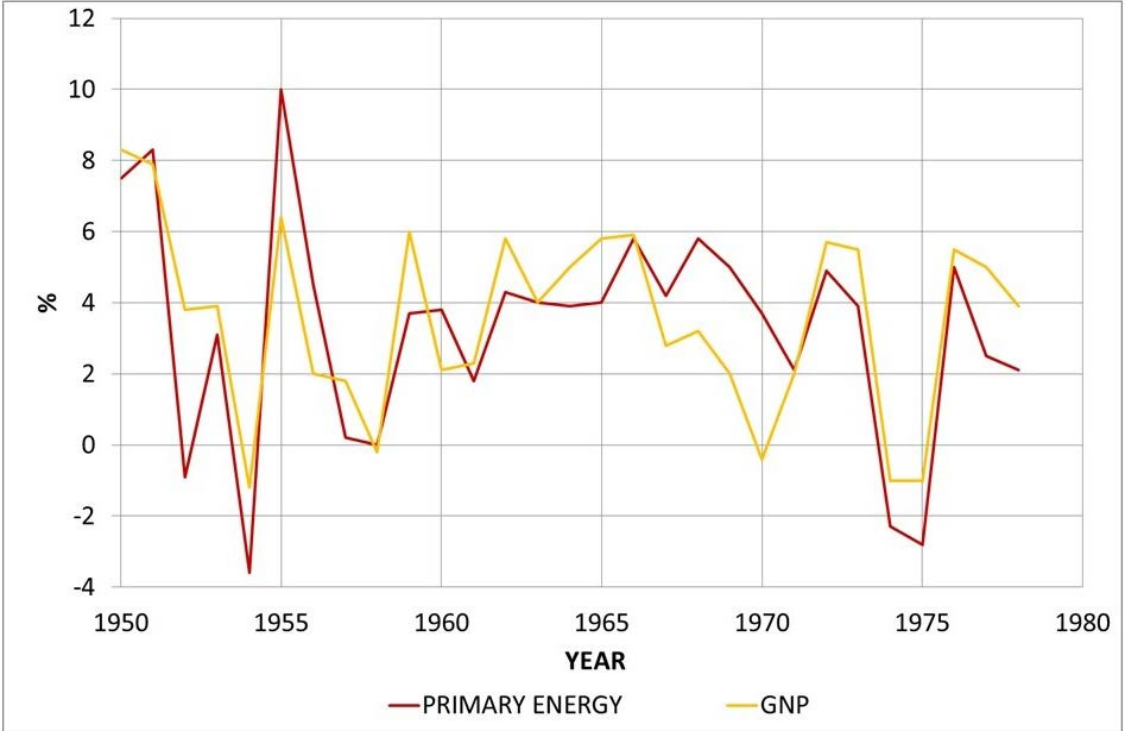

Fig. 2. Changes in GNP and primary energy consumption over time (actual data) (Ross 1986)

Rys. 2. Zmiany GNP i zużycia energii pierwotnej w funkcji czasu (dane rzeczywiste) (Ross 1986)

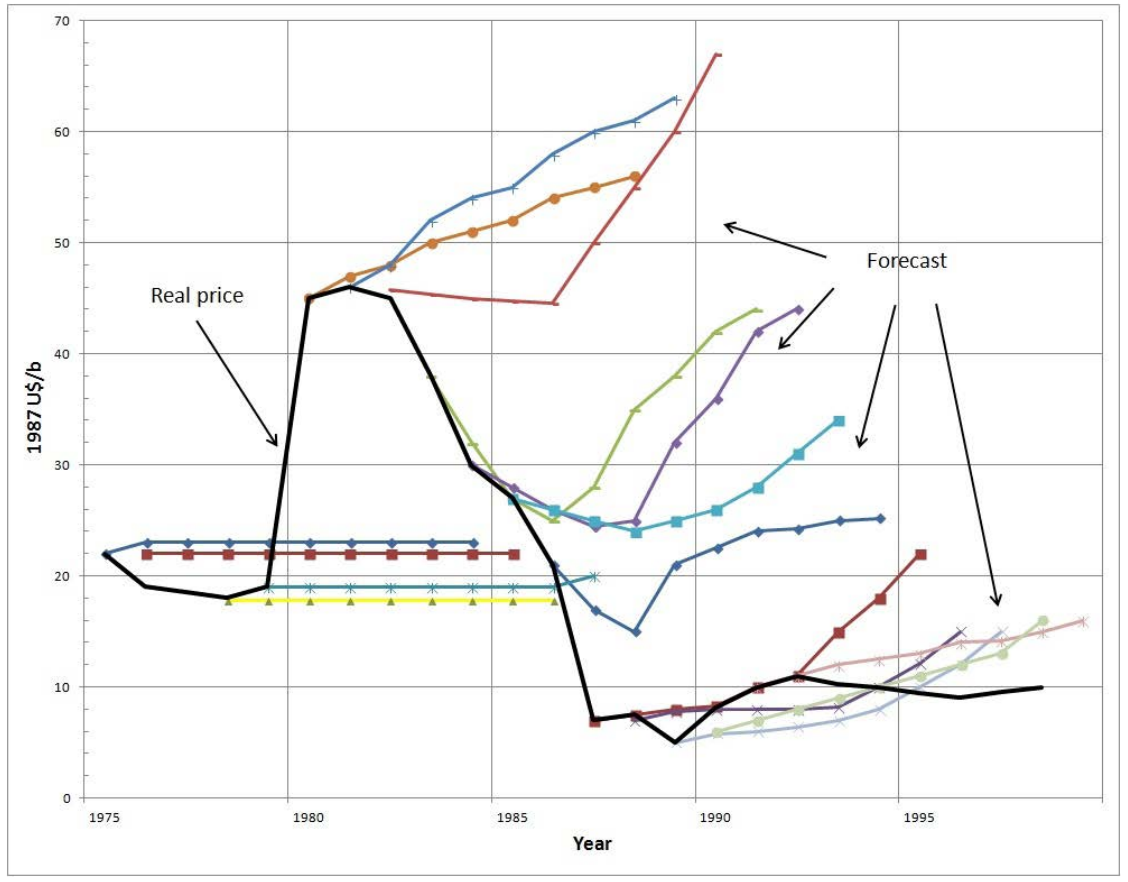

Fig. 3. Forecasts of oil prices (Kauffmann 1994)

Rys. 3. Prognozy cen ropy naftowej (Kauffmann 1994) 
urce of uncertainty. As an example, Fig. 3 shows the projections of oil prices, 1975-2000 (Kauffmann 1994).

Historical changes in oil prices in conjunction with various critical events are shown in Fig. 4.

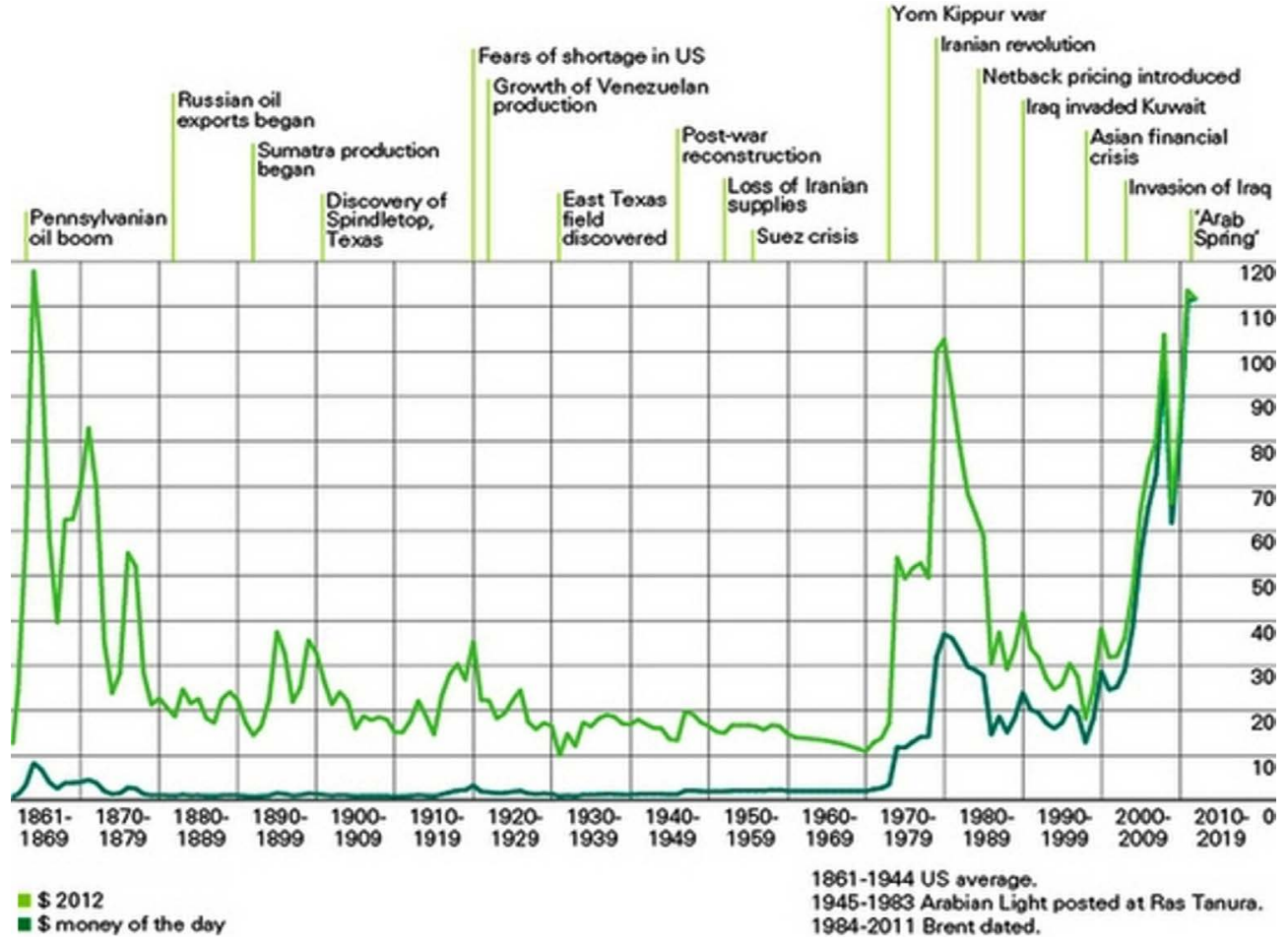

Fig. 4. Oil prices 1861-2013 (BP 2014)

Rys. 4. Ceny ropy naftowej 1861-2013 (BP 2014)

Well-designed predictive models of development forecast should take any potential risks which are likely to occur in the future into account, and identify the methods to reduce the negative effects of such changes. Dangerous situations may also emerge when primary energy importers are limited to only one source of imports without developing any diversification systems. Such approaches lead to breaches of national security affecting all core activities of a state.

As shown by the above considerations, the reliability of forecasting is affected by errors of the input data, the variations of which, over time, are random by nature and difficult to predict. Thus long-term forecasting, beyond 10 year intervals, ceases to meet its proper role as a predictor of planning the directions for national development.

This paper presents the results of selected projections, including those for Poland. The discrepancies between the conclusions derived from the forecasts and the actual data prove that improving forecasting methods on a continuous basis is essential. 


\section{Global Energy Projections}

This analysis of the results provided by selected global energy forecasts invites to discuss how various arbitrarily adopted variables impact the final results. This paper presents the results of several selected scenarios and compares them, where possible, with the actual data. We selected highly reliable and internationally renowned forecasts.

\subsection{WAES Forecast - Energy: Global Prospects, 1985-2000}

This forecast was developed in the 1970s and published as a report of the Workshop on Alternative Energy Strategies (WAES) (Wilson 1977). The project sponsored by the Massachusetts Institute of Technology (MIT), was directed by Carroll L. Wilson. Representatives of the following 15 countries worked on that report: Canada, Denmark, Finland, France, Germany, Iran, Great Britain, United States, Venezuela, Italy, Japan, Mexico, the Netherlands, Norway and Sweden, coming from universities, national research institutes, government agencies and major energy corporations. The results of that forecast are detailed below as a typical example of the methodology of making inferences.

Final report findings:

- The world oil production is likely to level off in 1985-1995, meaning that the oil production will stop meeting the demand, which will cause a need to find alternative energy sources. This phenomenon will occur even with a $50 \%$ price increase - it was a principle assumption to the project,

- Primary energy demand will grow despite intensive government activities aimed at achieving reasonable energy consumption;

- Finding and implementing alternative sources of primary energy will require from 5 to 10 years, which may lead to disruptions in energy balances at national levels;

- Power production with increased use of nuclear energy will play an important role in the energy balance;

- Coal will play the most important role as an alternative fuel due to the abundance of its natural resources;

- Natural gas may play an important role in ensuring the world energy balance provided the international transportation network undergoes a siginidicant expansion;

- Energy carriers derived from tar sands did not play a significant role before 2000;

- Renewable energy, i.e., hydropower, solar and wind energy, will not constitute major sources of energy,

- Improving energy efficiency and significant energy savings (up to $30 \%$ of primary energy consumption) will play an important role as an alternative source of energy;

- This critical situation resulting from the need to balance the supply and demand for primary energy will require unprecedented international cooperation. 
The following assumptions (for two variants of growth: high and low) were adopted for the calculations:

-1977-1985

- Average global GDP growth rate: $6 \%$ and 3.5\%,

- Price of oil per barrel: USD 17.25, USD 11.50 and USD 7.66,

- Stringent state policy reasonable use of energy.

1985-2000

- Average global GDP growth rate: $5 \%$ and 3\%,

- Price of oil per barrel: USD 17.25 and USD 11.50,

- Increases in oil reserves: $30 \mathrm{BB} / \mathrm{YR}$ and $10 \mathrm{BB} / \mathrm{YR}$,

- Reduction of oil production by OPEC countries to: $45 \mathrm{MBD}$ and $40 \mathrm{MBD}$,

- Substitute fuels for oil: coal or nuclear energy.

The forecasts for oil supply as a basic limitation in primary energy demand are shown in Fig. 5 (the data cover the countries referred to as the World Outside Communist Areas (WOCA) in the report).

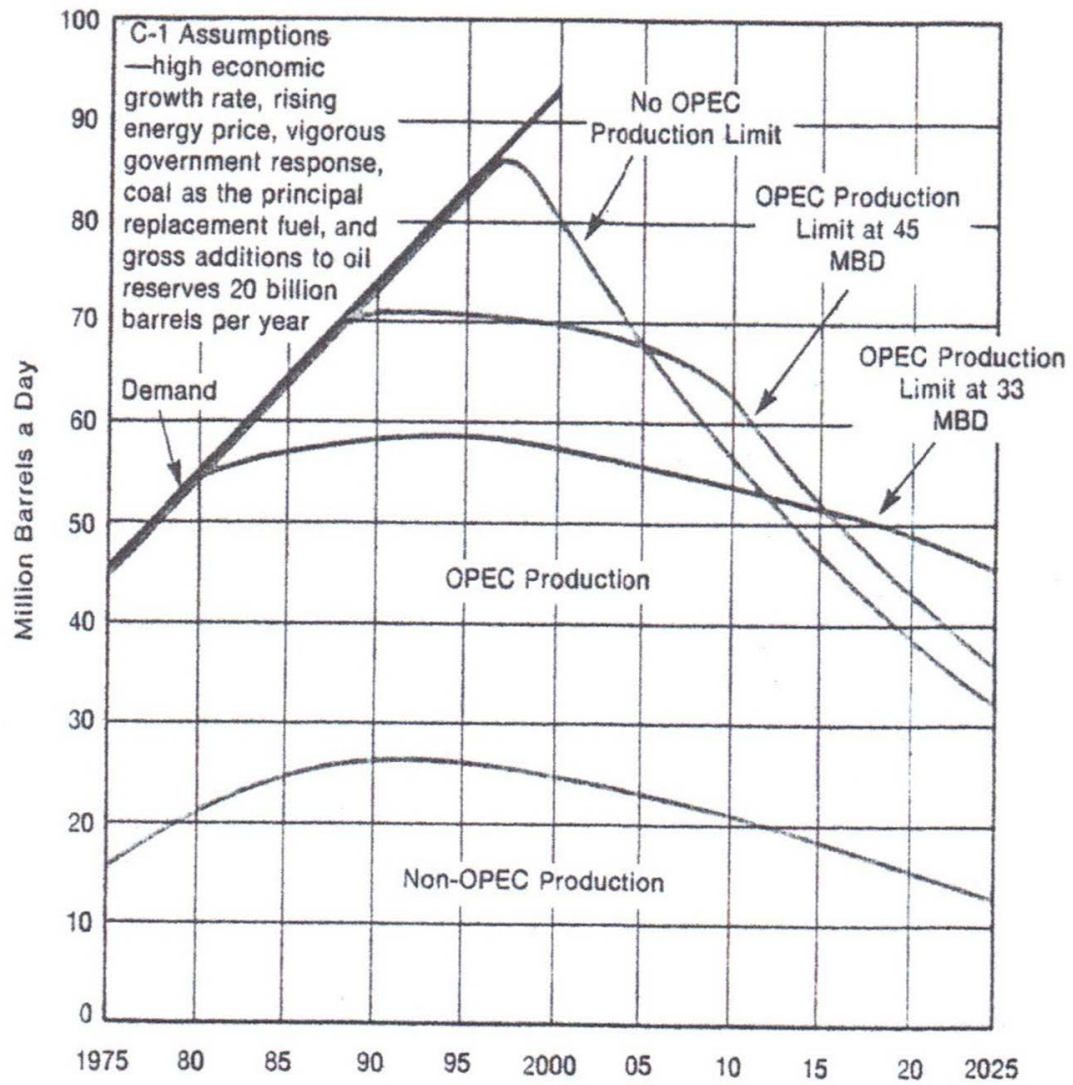

Fig. 5. Forecasts for oil in the WAES report (Wilson 1977)

Rys. 5. Prognozy wydobycia ropy w raporcie WAES (Wilson 1977) 
Some projection results for 2000 are given below:

- Primary energy demand: (12.0 to 15.12$) 10^{9}$ tce/year,

- Annual growth of power production (with a power plant efficiency of 35\%): 4-5\%,

- The growth rate of primary energy demand: $5 \% /$ year.

The actual values for 2000 (BP 2013):

- Primary energy consumption: $10.73 \cdot 10^{9}$ tce/year,

- Annual growth of power production: 3 to $4 \%$,

- The growth rate of primary energy consumption: $3.5 \% / y e a r$.

The divergence in primary energy consumption is particularly noticeable. The forecast is overstated up to $34 \%$ of the maximum demand. The cause of the inconsistency was a rise in oil prices from the 1970s to the 1980s.

\subsection{International Atomic Energy Agency (IAEA) Forecast}

The demand indicators for the world primary energy consumption (averaged values) from 2000 to 2015 and their actual equivalents are shown below.

Table 1. Comparison of the demand indicators for the world primary energy consumption

Tabela 1. Wskaźnik zapotrzebowania zużycia energii pierwotnej dla świata

\begin{tabular}{|c|c|c|c|c|}
\hline & Year & 2000 & 2010 & 2015 \\
\hline \multirow{2}{*}{$\begin{array}{c}\text { Primary energy } \\
{\left[10^{6} \text { tce/year }\right]}\end{array}$} & Forecast (A Summary of Energy 1996) & $9,738.0$ & $11,338.0$ & \multirow{2}{*}{$12,340.8$} \\
\hline & Actual consumption (BP 2014) & $9,293.0$ & $11,955.5$ & \\
\hline \multirow{2}{*}{$\begin{array}{l}\text { Annual growth in } \\
\text { energy use [\%] }\end{array}$} & Forecast (A Summary of Energy 1996) & 2.5 & 2.40 & \multirow{2}{*}{2.00} \\
\hline & Actual consumption (BP 2014) & 2.3 & 2.20 & \\
\hline \multirow{2}{*}{$\begin{array}{c}\text { Energy consumption } \\
\text { per capita }[\text { tce/ca] }\end{array}$} & Forecast (A Summary of Energy 1996) & 2.21 & 2.25 & \multirow{2}{*}{2.32} \\
\hline & Actual consumption (BP 2014) & 2.18 & 2.26 & \\
\hline
\end{tabular}

The above data allow for the conclusion that forecasts are in good compliance with the actual values. It is, however, a mid-term outlook enabling comparisons over a 10-year interval.

\subsection{Forecasts to 2030,2035 and 2040}

Forecasts to 2030 and 2035 (BP 2012; BP 2014; International Energy Outlook 2013) contain long-term predictions. Their comparison will be presented below. 
BP Forecasts to 2030 and 2035

The BP forecasts were developed based on the data for 2012, (BP Energy Outlook 2030) and 2014 (BP Energy Outlook 2035), respectively. The 2035 Forecast is an extension of the previous predictions, taking new energy sources (shale gas in the United States) and more reliable input data into account. In the 2035 projection, the authors ask three fundamental questions:

1. Will the world have sufficient energy to support the expected civilisation growth? The answer is positive. It is very likely that global primary energy demand will increase by 2035 by more than $40 \%$, and $95 \%$ of this growth will by generated by the countries with a high GDP. There will be new sources of primary energy such as shale gas and oil, the use of different types of renewable energy will grow significantly, and energy efficiency will be increased in a wide range of primary and final energy uses.

2. Will energy security be ensured at national levels?

Only the United States will be able to attain energy self-sufficiency. The dependence on energy sources of the European Union, China, Japan and India will increase. Russia will remain a major exporter of energy, in particular, of oil and gas. The Middle East countries will remain stable exporters.

3. Will the environmental hazards caused by the development of energy systems be successfully addressed?

The estimates indicate that $\mathrm{CO}_{2}$ emissions will increase by $29 \%$ by 2035 . The reduction in the rate of their growth, mainly due to increased share of gas used as fuel in power plants, and a significant increase in the use of renewable energy sources, should be perceived positively.

Basic assumptions to the two projections are shown below. Global development trends are shown in Figs. 6 and 7 (2030 and 2035, respectively).

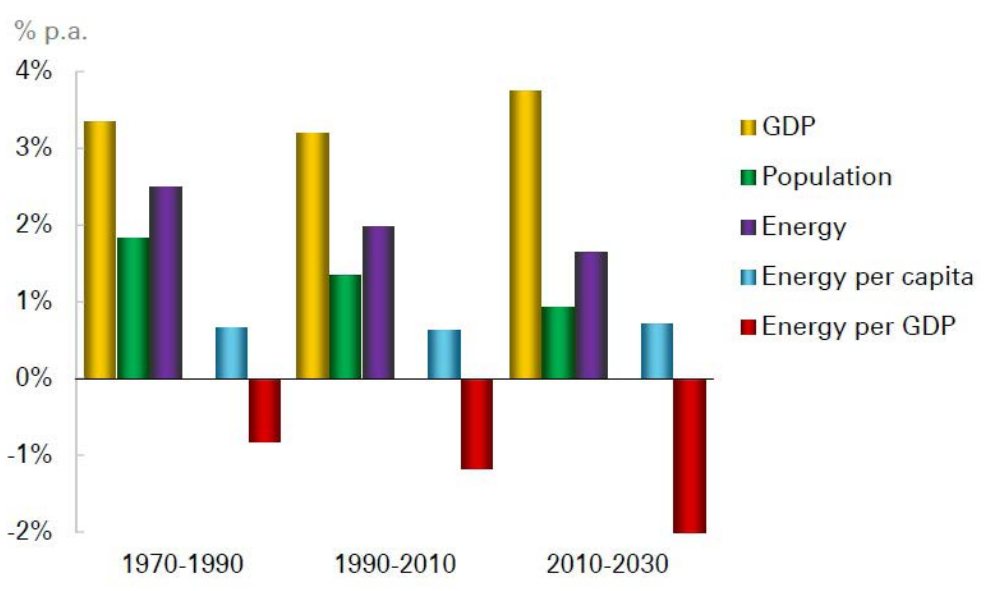

Fig. 6. Global value growth by 2030 (BP 2012) 


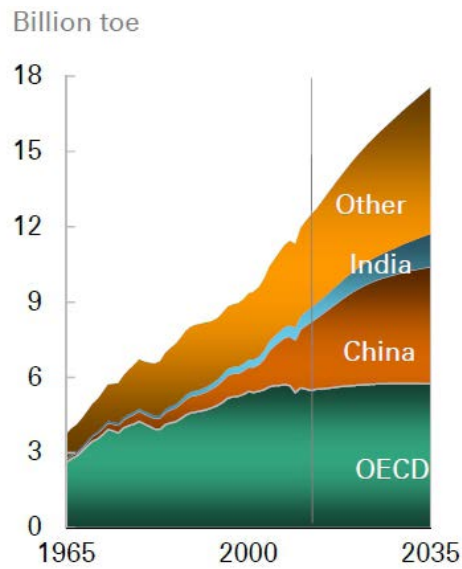

Fig. 7. Primary energy demand by 2035 (BP 2014)

Rys. 7. Zapotrzebowanie na energię pierwotną do roku 2035 (BP 2014)

Detailed input data (BP 2012; BP 2014):

- World population growth: $0.9 \%$ (2015-2030),

- GDP growth: 3.7\%/year (2020-30) and 3.5\%/year (2012-35),

- Growth rate of energy efficiency: 1.2\%/year (2030) and 1.9\%/year (2035),

- Growth rate of primary energy consumption: 1.6\%/year (2030), 1.5\%/year (2035), with as average values for 2.2\%/year (2005-15) 1.7\%/year (2015-25), 1.1\%/year (in 2025-35),

- $95 \%$ of the growth in primary energy consumption will apply to non-OECD countries (2.7\%/year) (or 1.6\%/year per capita) (2030) with 2.3\%/year (2035). For OECD countries it will be $0.2 \% /$ year $(-0.2 \% /$ year per capita) (2030) and $0.2 \% /$ year (2035), respectively.
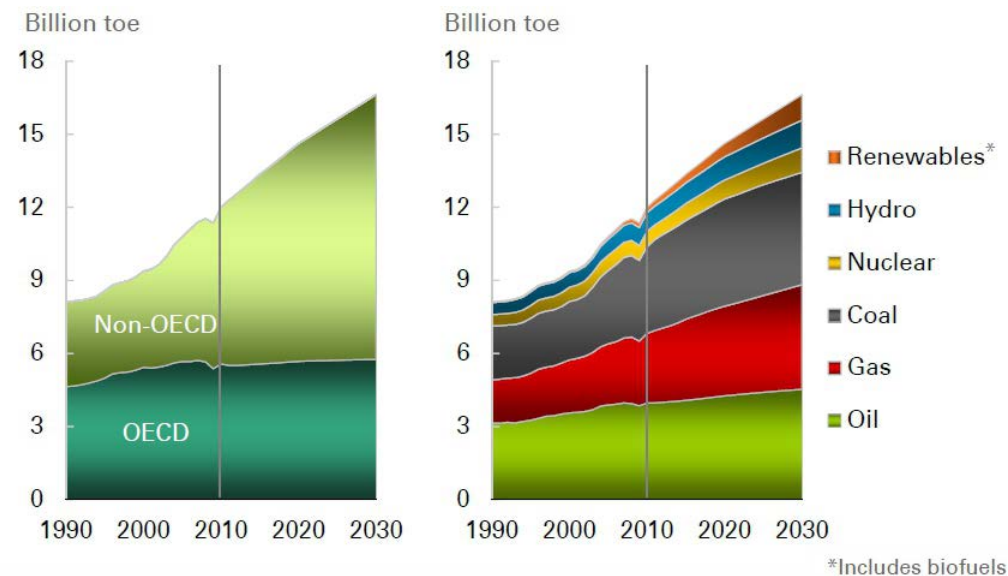

Fig. 8. Primary energy demand to 2030 (BP 2012)

Rys. 8. Zapotrzebowanie na energię pierwotną do roku 2030 (BP 2012) 
The projected results are shown in Figs. 8 and 9.

The changes in energy efficiency and energy use by type are shown in Fig. 10.
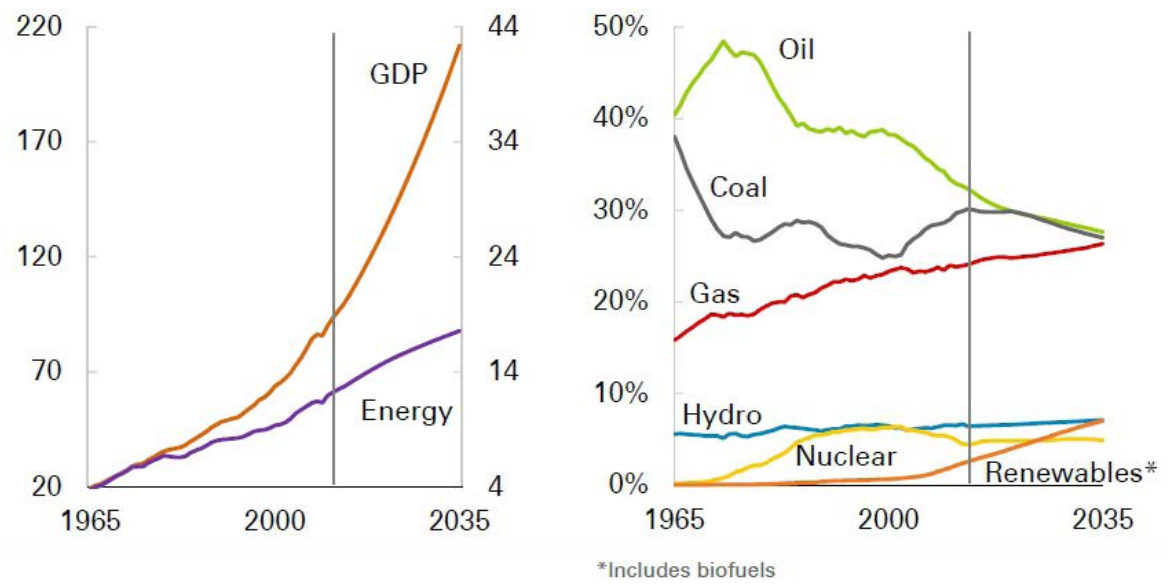

Fig. 9. GDP growth and primary energy shares to 2035 (BP 2014)

Rys. 9. Wzrost PKB oraz udziały w energii pierwotnej do roku 2035 (BP 2014)
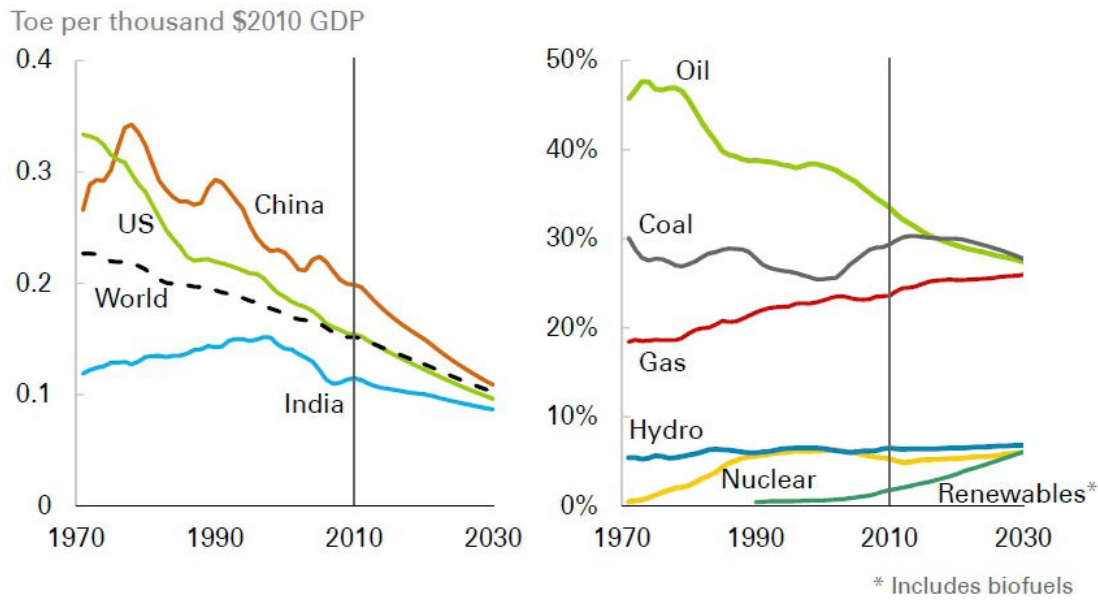

Fig. 10. Energy efficiency and primary energy shares to 2030 (BP 2012)

Rys. 10. Efektywność energetyczna oraz udziały w energii pierwotnej do roku 2030 (BP 2012)

Figs. 12 and 13 show a summary comparison of the results from different forecasts. It is worth noticing that the forecast with the lowest primary energy demand was developed by the International Energy Agency (IEA) in the New Policies Scenario (NPS) as compared to the IEA Current Policies Scenario (CPS). 


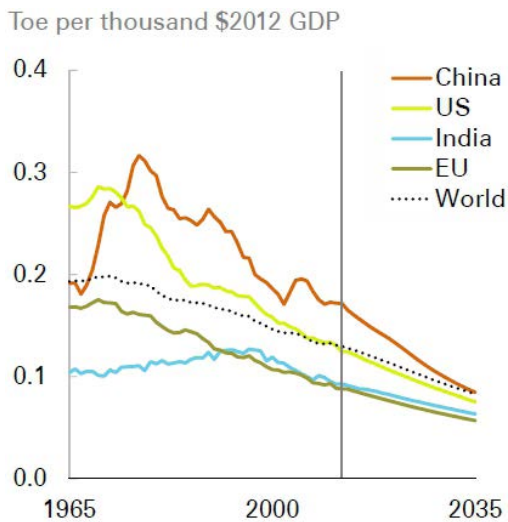

Fig. 11. Energy efficiency, 2035 (BP 2014)

Rys. 11. Efektywność energetyczna 2035 (BP 2014)

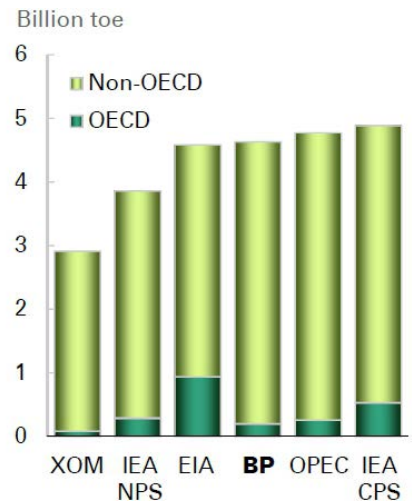

Fig. 12. Forecasts of demand for primary energy to 2030 (BP 2012)

Rys. 12. Prognozy zapotrzebowania na energię pierwotną 2030 (BP 2012)

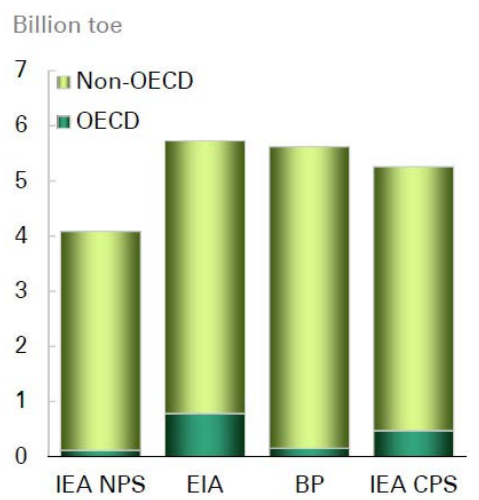

Fig. 13. Forecasts of demand for primary energy to 2035 (BP 2014)

Rys. 13. Prognozy zapotrzebowania na energię pierwotną 2035 (BP 2014) 
The analyses of assumptions made to both forecasts indicate that the adopted extrapolations were largely arbitrary (Figs. 10 and 11). Moreover, these forecasts are global which means that the input data were significantly averaged and the passive nature of changes was tacitly adopted.

\subsection{US Energy Information Administration (EIA) Forecast to 2040}

The increase in demand for primary energy by 2040 adopted in that forecast is shown in Fig. 14 (International Energy Outlook 2013).

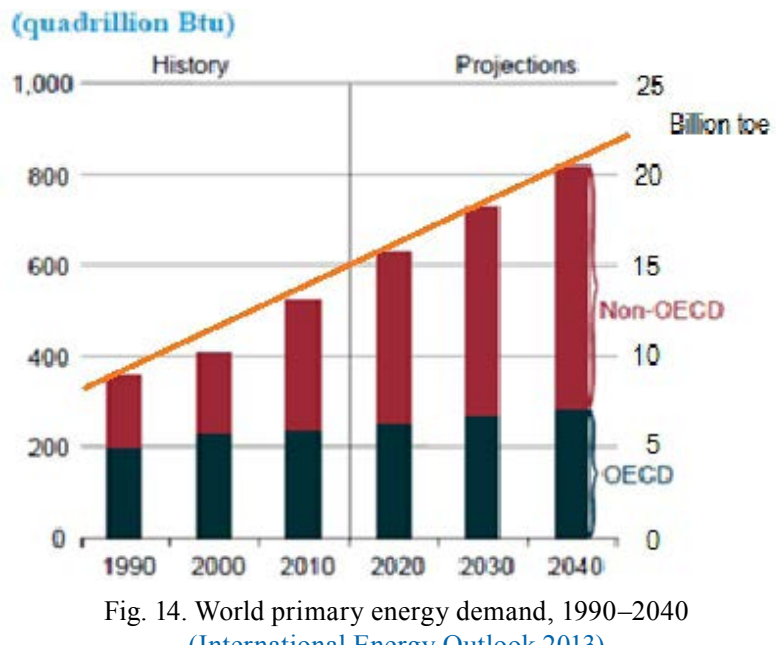

Rys. 14. Światowe zapotrzebowanie na energię pierwotną 1990-2040 (International Energy Outlook 2013)

Basic data adopted for that projection:

- Growth in primary energy demand by 20\% in 2010-2020 and 30\% in 2020-2030,

- About $85 \%$ of this demand growth will occur in the developing non-OECD countries,

- Average world GDP growth rate will be 3.6\% (2010-2040), with 4.7\%/year for developing countries, and 2.1\%/year for OECD countries.

The adopted scenario is shown in Fig. 15 (International Energy Outlook 2013) (arbitrary extrapolation should be emphasized).

Further details can be found in (International Energy Outlook 2013). 


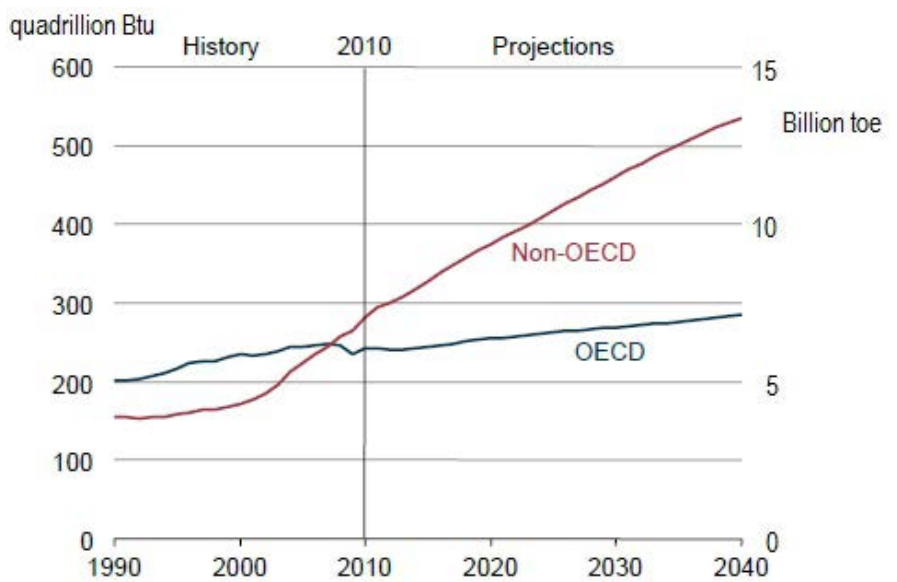

Fig. 15. Primary energy demand in OECD and developing countries (International Energy Outlook 2013)

Rys. 15. Zapotrzebowanie na energię pierwotną w krajach OECD oraz rozwijających się (International Energy Outlook 2013)

\subsection{The Sensitivity Analysis of the US EIA Forecast}

While other projections do not address the issue of their uncertainty, the EIA forecast includes a sensitivity analysis taking a potential variability of the input values into account. Among many variables, the variations of GDP and energy prices over time influence the final results most significantly. Figs. 16 and 17 show the volatility of average GDP on for the world and selected countries (arbitrary extrapolation adopted).

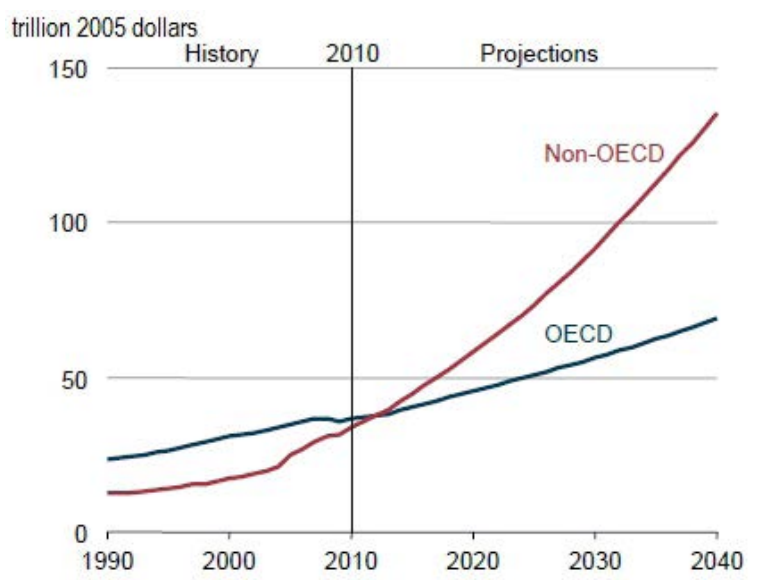

Fig. 16. Changes in the world GDP (International Energy Outlook 2013)

Rys. 16. Zmiany PKB dla świata (International Energy Outlook 2013) 


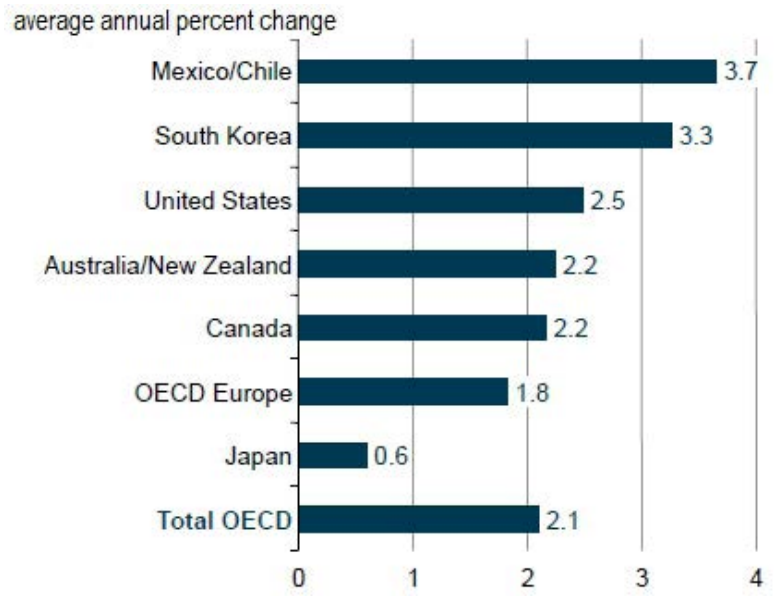

Fig. 17. Changes in GDP for selected countries, 2010-2040 (International Energy Outlook 2013)

Rys. 17. Zmiany PKB dla wybranych krajów w latach 2010-2040 (International Energy Outlook 2013)

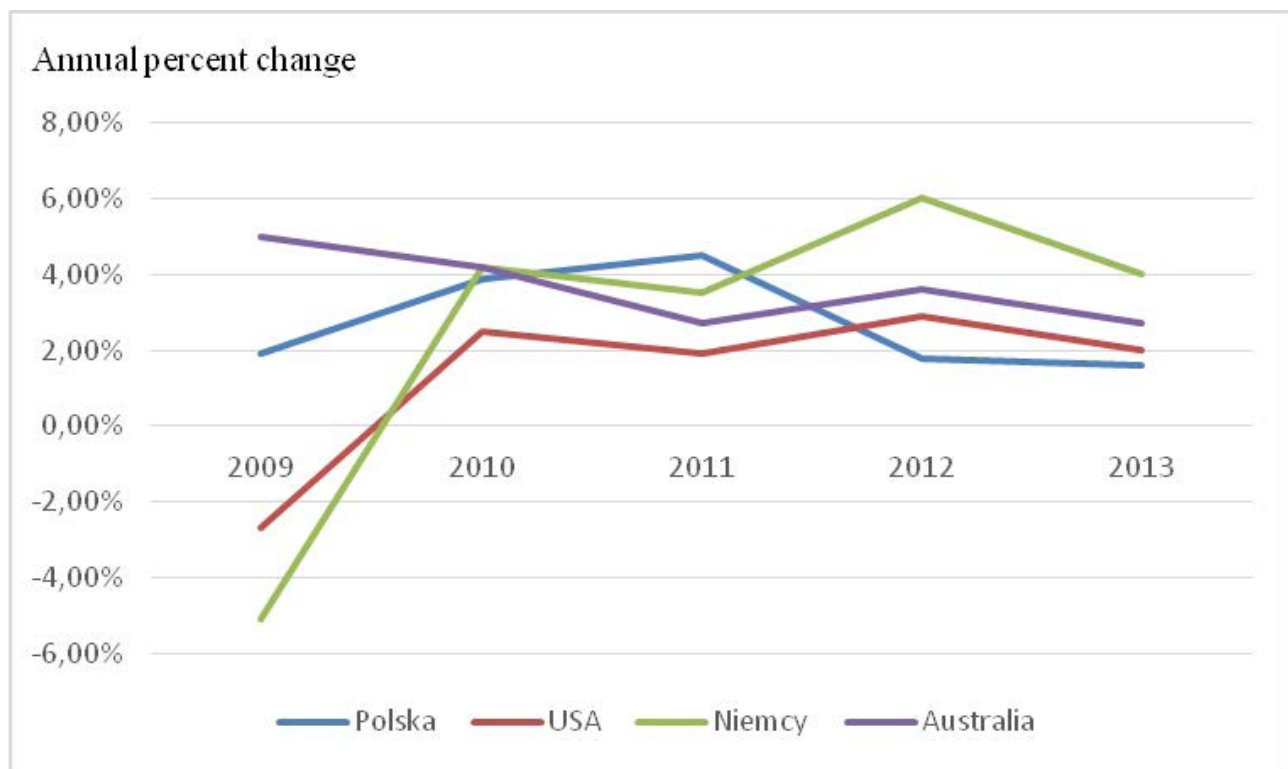

Fig. 18. Changes in GDP over time for selected countries based on (International Energy Outlook 2013)

Rys. 18. Roczne zmiany PKB dla wybranych krajów według (International Energy Outlook 2013) 


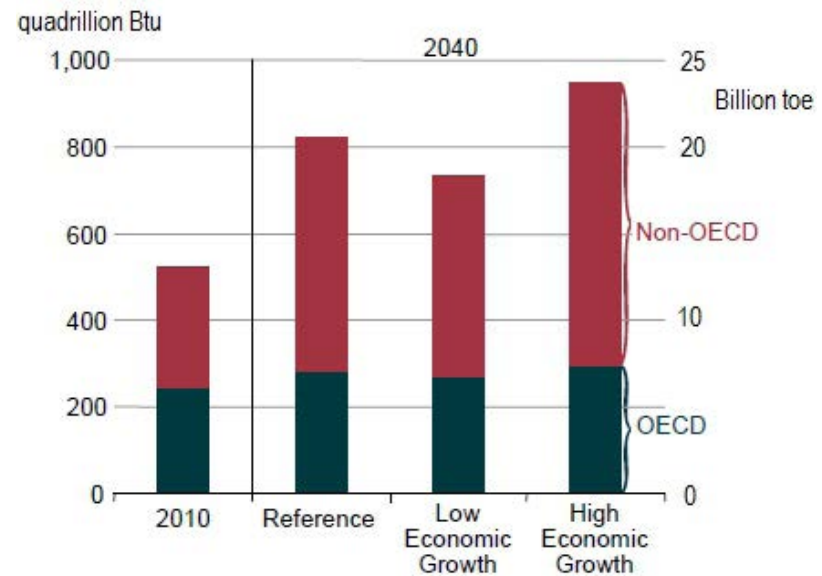

Fig. 19. Global primary energy demand for several scenarios of GDP changes (International Energy Outlook 2013)

Rys. 19. Zapotrzebowanie na energię pierwotną świata dla różnych scenariuszy zmian PKB (International Energy Outlook 2013)

In addition to average values, annual changes in GDP play an important role. Fig. 18 shows changes in GDP over time for selected countries.

The summarised sensitivity analysis of the changes in GDP is shown in Fig. 19.

High GDP growth: $2.3 \%$ year in OECD countries (2.1\% in the reference scenario) and $5.2 \% /$ year in non-OECD countries.

Low GDP growth: $1.9 \%$ year in OECD countries $(2.2 \%$ in the reference scenario) and $4.1 \% /$ year non-OECD countries.

The assumptions for oil prices in the different scenarios are (b-barrels):

- Reference scenario: USD 110/b (2011 dollars) in 2012, USD 163/b in 2040 with reduced oil production by OPEC countries to $46.4 \cdot 10^{6}$ b/day in 2040 ,

- GDP growth rate: $4.7 \%$ /year,

- High price growth scenario: USD 75/b (2011 dollars) in 2040 (an increase in OPEC production to $51 \%$ of the world production),

- GDP growth rate: $4.3 \% / y e a r$,

- Low price growth scenario: USD 23/b (2011 dollars) in 2040 (OPEC production: $65.7 \mathrm{~b} /$ day),

- GDP growth rate in non-OECD countries: 5.1\%/year.

\section{Energy Outlook for Poland, 1978-2030}

The reliability of energy forecasts for Poland is illustrated by the results of selected scenarios. The authors of this paper do not discuss the forecasting methods and basic assumptions used in them. The objective here is to compare the projected results with the actual data. 


\subsection{Kopecki's Forecast, 1976}

Table 2. Forecast (Kopecki 1976) and actual consumption of primary energy [ $10^{6}$ tce/year] (World Energy Council 2007)

Tabela 2. Prognoza (Kopecki 1976) i zużycie rzeczywiste energii pierwotnej [ $10^{6}$ tce/rok] (World Energy Council 2007)

\begin{tabular}{|c|c|c|c|c|c|c|}
\hline \multirow{2}{*}{} & \multicolumn{2}{|c|}{1980} & \multicolumn{2}{c|}{1990} & \multicolumn{2}{c|}{2000} \\
\cline { 2 - 7 } & Forecast & $\begin{array}{c}\text { Actual } \\
\text { consumption }\end{array}$ & Forecast & $\begin{array}{c}\text { Actual } \\
\text { consumption }\end{array}$ & Forecast & $\begin{array}{c}\text { Actual } \\
\text { consumption }\end{array}$ \\
\hline World & 12,200 & 9,265 & 20,200 & 12,700 & 32,900 & 14,233 \\
\hline Poland & 200 & 175.7 & 324 & 143.7 & 462 & 130.7 \\
\hline
\end{tabular}

Table 3. Global demand and consumption of primary energy. Forecast to 2000 (Kopecki 1976) and actual data $\left[10^{6}\right.$ tce/year] (World Energy Council 2007)

Tabela 3. Światowe zapotrzebowanie i zużycie nośników energii pierwotnej. Prognoza 2000 (Kopecki 1976) i dane rzeczywiste $\left[10^{6}\right.$ tce/rok] (World Energy Council 2007)

\begin{tabular}{|l|c|c|}
\hline \multicolumn{1}{|c|}{ Item } & Forecast to 2000 & Actual consumption \\
\hline Primary energy & 32,900 & 14,233 \\
\hline Coal & 4,200 & 3,344 \\
\hline Oil & 13,750 & 4,962 \\
\hline Natural gas & 6,800 & 3,001 \\
\hline Hydropower and geothermal energy & 820 & 323 \\
\hline Nuclear energy & 6,970 & 966 \\
\hline Other & - & 1,636 \\
\hline
\end{tabular}

Table 4. Demand and consumption of domestic primary energy and its sources. Forecast (Kopecki 1981) and actual consumption (International Energy Outlook 2013) [106 tce/year]

Tabela 4. Zapotrzebowanie i zużycie krajowej energii pierwotnej i jej nośników. Prognoza (Kopecki 1981) i zużycie rzeczywiste (International Energy Outlook 2013) [106 tce/rok]

\begin{tabular}{|l|c|c|}
\hline \multicolumn{1}{|c|}{ Item } & Forecast to 2000 & Actual consumption \\
\hline Primary energy & 462 & 130.7 \\
\hline Coal & 202 & 84.3 \\
\hline Oil & 124 & 24.3 \\
\hline Natural gas & 62 & 16. \\
\hline Hydro energy & 2.5 & 6.1 \\
\hline Nuclear energy & 51 & 0 \\
\hline
\end{tabular}


Table 5. Year 2000 - selected forecasts of primary energy demand (Ney 1988)

Tabela 5. Rok 2000 - niektóre prognozy zapotrzebowania w energię pierwotną (Ney 1988)

\begin{tabular}{|c|c|}
\hline Forecast & Global demand in 106 tce/year \\
\hline $\begin{array}{l}\text { Kopecki PAN [Polish Academy of Sciences], } 1976 \\
\text { High rising growth } \\
\text { Low rising growth }\end{array}$ & $\begin{array}{l}406 \\
315\end{array}$ \\
\hline $\begin{array}{l}\text { Kopecki PAN, } 1981 \\
\text { High rising growth } \\
\text { - Low rising growth }\end{array}$ & $\begin{array}{l}280 \\
260\end{array}$ \\
\hline $\begin{array}{l}\text { GIGE, 1982, J. Michna } \\
\text { - Moderate case } \\
\text { - Zero growth case (Ney 1988) }\end{array}$ & $\begin{array}{l}235 \\
195\end{array}$ \\
\hline $\begin{array}{l}\text { J. Filipowicz, } 1982 \\
\text { - High rising growth } \\
\text { Low rising growth (Ney 1988) }\end{array}$ & $\begin{array}{l}250 \\
220\end{array}$ \\
\hline $\begin{array}{l}\text { R. Nodzyński, 1982-83 } \\
\text { High rising growth } \\
\text { - Low rising growth (Ney 1988) }\end{array}$ & $\begin{array}{l}280 \\
260\end{array}$ \\
\hline $\begin{array}{l}\text { J. Cofała, } 1983 \\
\text { - High rising growth } \\
\text { Low rising growth (Ney 1988) }\end{array}$ & $\begin{array}{l}244 \\
213\end{array}$ \\
\hline $\begin{array}{l}\text { J. Soliński, } 1983 \\
\text { - High rising growth } \\
\text { - Low rising growth (Ney 1988) }\end{array}$ & $\begin{array}{l}245 \\
226\end{array}$ \\
\hline $\begin{array}{l}\text { The Planning Commission and the Ministry of Economy and Energy } \\
\text { (MEE), } 1985 \\
\text { - Non-rationalized } \\
\text { Rationalized (Ney 1988) }\end{array}$ & $\begin{array}{l}320 \\
250\end{array}$ \\
\hline $\begin{array}{l}\text { R. Ney, } 1985 \\
\text { - level } 1 \\
\text { - level } 2 \\
\text { - level } 3 \text { (Ney 1988) }\end{array}$ & $\begin{array}{l}264 \\
244 \\
223\end{array}$ \\
\hline $\begin{array}{l}\text { Forecast by the KPE-PAN [Committee for the Energy Challenges of } \\
\text { the Polish Academy of Sciences],1986 } \\
\text { - High rising growth } \\
\text { - Moderate case } \\
\text { - Low rising growth (Ney 1988) }\end{array}$ & $\begin{array}{l}250 \\
225 \\
200\end{array}$ \\
\hline $\begin{array}{l}\text { MEE, } 1987 \\
\text { - Non-rationalized } \\
\text { - Rationalized (Ney 1988) }\end{array}$ & $\begin{array}{l}250 \\
240\end{array}$ \\
\hline
\end{tabular}


According to that forecast, half-depletion of energy resources will be reached in Poland as follows:

- coal - around 2600,

- oil - around 2013,

- natural gas - around 2002

Those values fail to coincide with the actual status.

\subsection{Forecasts, 1978-1987 (Poland)}

The forecast results are based on a paper by R. Ney presented at the conference "Fuel and Energy Supplies as a Pre-Condition for the functioning of the national economy" (Ney 1988).

Table 6. Actual consumption (World Energy Council 2007)

Tabela 6. Zużycie rzeczywiste (World Energy Council 2007)

\begin{tabular}{|c|c|}
\hline Year & Actual consumption (World Energy Council 2007) \\
\hline 1970 & 121.0 \\
\hline 1980 & 177.9 \\
\hline 1990 & 143.7 \\
\hline 2000 & 130.7 \\
\hline 2005 & 130.0 \\
\hline
\end{tabular}

\subsection{PAN Forecast, 1991 (Polish Academy of Sciences)}

Table 7. Demand forecast (Collective work: Forecast 1991) and actual consumption of primary energy (World Energy Council 2007) [106 tce/year]

Tabela 7. Prognoza zapotrzebowania (Collective work: Ekspertyza 1991) i rzeczywiste zużycie energii pierwotnej (World Energy Council 2007) [10 6 tce/rok]

\begin{tabular}{|c|c|c|c|}
\hline \multicolumn{1}{|c|}{ Year } & 1990 & 2000 & 2010 \\
\hline Primary energy demand, forecast & 152.0 & 180.0 & 222.0 \\
\hline Actual consumption & 143.7 & 130.7 & 142.1 \\
\hline
\end{tabular}




\subsection{PAN Forecast, 1994 (Polish Academy of Sciences)}

The forecast of demand for primary energy is shown in the Table below for the development variant (PAN Forecast 1994).

Table 8. Demand forecast (PAN Forecast 1994) and actual consumption (World Energy Council 2007) $\left[10^{6}\right.$ tce/year $]$

Tabela 8. Prognoza zapotrzebowania (PAN Ekspertyza 1994) i rzeczywiste zużycie energii pierwotnej (World Energy Council 2007) $\left[10^{6}\right.$ tce/rok]

\begin{tabular}{|l|l|l|l|}
\hline \multicolumn{1}{|c|}{ Year } & 1990 & 2000 & 2010 \\
\hline Primary energy demand, forecast & 142.6 & 145.6 & 153.4 \\
\hline Actual consumption & 143.7 & 130.7 & 142.1 \\
\hline
\end{tabular}

\subsection{PAN Forecast, 1997 (Polish Academy of Sciences)}

Table 9. Demand forecast (PAN Forecast 1997) and actual consumption of primary energy (World Energy Council 2007) [106 tce/year]

Tabela 9. Prognoza zapotrzebowania (PAN Ekspertyza 1997) i rzeczywiste zużycie energii pierwotnej (World Energy Council 2007) [10 6 tce/rok]

\begin{tabular}{|l|c|c|c|}
\hline \multicolumn{1}{|c|}{ Year } & 1995 & 2000 & 2010 \\
\hline Primary energy demand, forecast & 151.9 & 156.9 & 168.7 \\
\hline Actual consumption & 143.7 & 130.7 & 142.1 \\
\hline
\end{tabular}

\subsection{Forecast of the Ministry of Economy, 1999}

Table 10. Demand forecast (Polityka Energetyczna Polski do 2020 roku 1999) and actual consumption of primary energy (World Energy Council 2007) [10 $10^{6}$ tce/year] (Progress variant)

Tabela 10. Prognoza zapotrzebowania (Polityka Energetyczna Polski do 2020 roku 1999) i rzeczywiste zużycie energii pierwotnej (World Energy Council 2007) [10 6 tce/rok] (wariant postępu)

\begin{tabular}{|l|c|c|c|c|}
\hline \multicolumn{1}{|c|}{ Year } & 2005 & 2010 & 2015 & 2020 \\
\hline Primary energy demand, forecast & 152.7 & 167.4 & 173.1 & 186.3 \\
\hline Actual consumption & 130.0 & 142.1 & \\
\hline
\end{tabular}




\subsection{Forecast by the Energy Policy Group of the Ministry of Economy (MEL), 2004}

The selected results of the expertise are shown below.

Table 11. Demand forecast (Polityka Energetyczna Polski do 2025 roku 2004) and actual consumption of primary energy (World Energy Council 2007) (106 tce/year) (Efficiency variant)

Tabela 11. Prognoza zapotrzebowania (Polityka Energetyczna Polski do 2025 roku 2004) i rzeczywiste zużycie energii pierwotnej (World Energy Council 2007) (106 tce/rok) (wariant efektywności)

\begin{tabular}{|l|l|l|l|l|l|}
\hline \multicolumn{1}{|c|}{ Year } & 2005 & 2010 & 2015 & 2020 & 2025 \\
\hline Primary energy demand, forecast & 133.3 & 147.0 & 154.3 & 165.7 & 185.7 \\
\hline Actual consumption & 130.0 & 142.1 & \multicolumn{3}{|r}{} \\
\cline { 1 - 4 } & &
\end{tabular}

2.8. Forecast of demand for fuels and energy by 2030 .

Ministry of Economy, 2009

The forecast of demand for primary energy and electricity developed by the Ministry of Economy in 2009 projects as follows:

Table 12. Demand forecast (Polityka Energetyczna Polski do 2020 roku 1999)

and actual consumption of primary energy (World Energy Council 2007) (10 6 tce/year)

Tabela 12. Prognoza zapotrzebowania (Polityka Energetyczna Polski do 2020 roku 1999) i rzeczywiste zużycie energii pierwotnej (World Energy Council 2007) (106 tce/rok)

\begin{tabular}{|l|c|c|c|c|c|c|}
\hline \multicolumn{1}{|c|}{ Year } & 2006 & 2010 & 2015 & 2020 & 2025 & 2030 \\
\hline Primary energy demand, forecast & 139.7 & 133.1 & 136.9 & 145.3 & 158.6 & 169.3 \\
\hline Actual consumption & 130.0 & 142.1 & &
\end{tabular}

\subsection{Forecast of the Strategic Analyses Department}

“The Optimal Energy Mix for Poland to 2060, DAS Model of August 9, 2013"

The analysis of that forecast raises an important question as to its basic assumption since the discussed forecast was made for 46 years into the future (to 2060) for which there is no rationale. Such a long period of time makes every extrapolation completely arbitrary and is not acceptable. The authors feel entitled to make such conclusions because of the basic data shown in Figs. 20 and 21. 


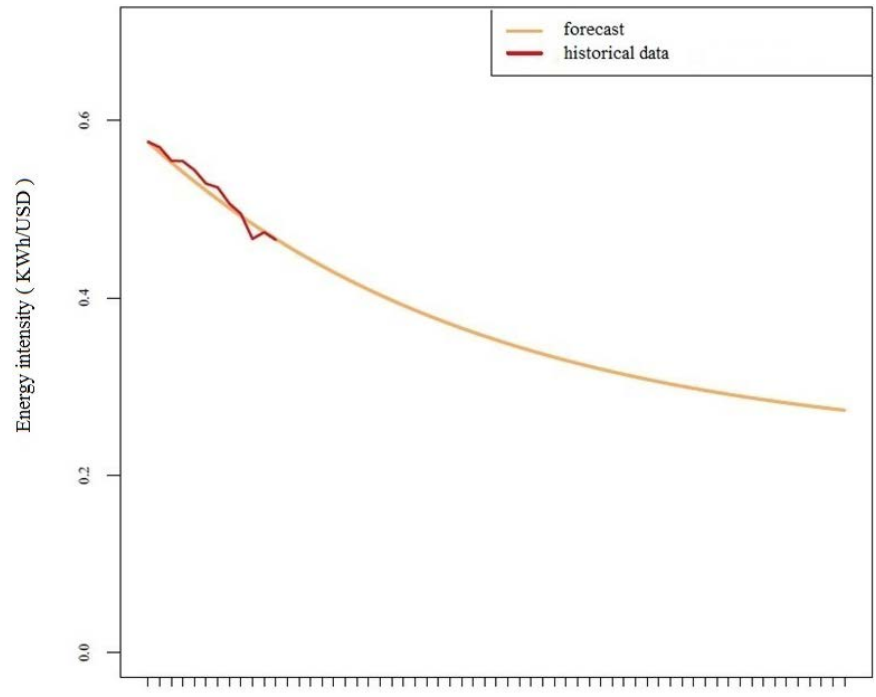

$\begin{array}{llllllllllllllll}2000 & 2004 & 2008 & 2012 & 2016 & 2020 & 2024 & 2028 & 2032 & 2036 & 2040 & 2044 & 2048 & 2052 & 2056 & 2060\end{array}$ Year

Fig. 20. Energy intensity, historical data and forecast

(Optymalny Miks energetyczny dla Polski do roku 2060 - Model DAS 2013)

Rys. 20. Energochłonność - dane historyczne i prognoza

(Optymalny miks energetyczny dla Polski do roku 2060 - Model DAS 2013)

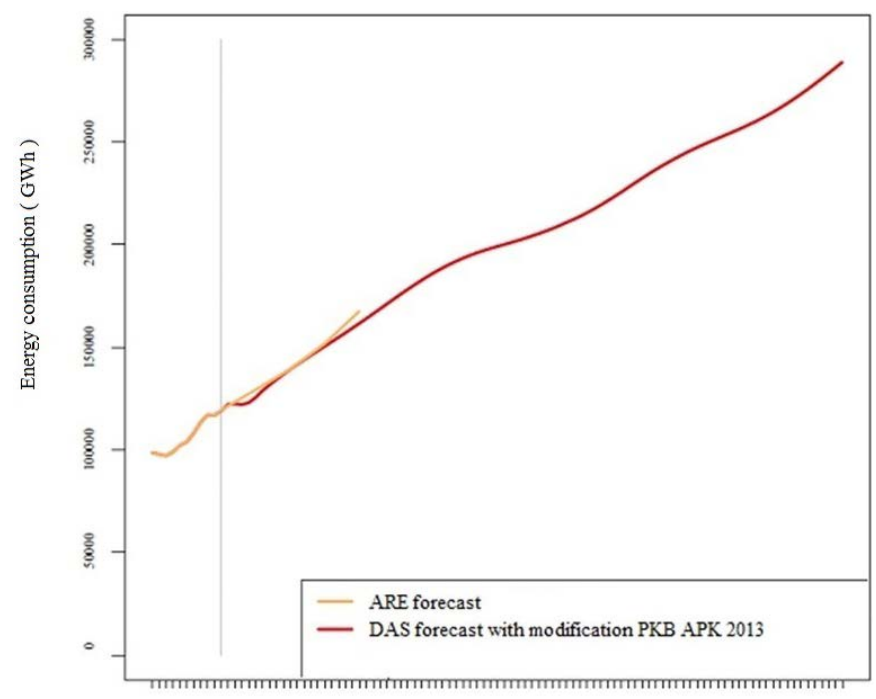

$200020062012201820242030203620422048205420602065 \quad 2072 \quad 2078205420902096$ Year

Fig. 21. Electricity consumption forecast

(Optymalny miks energetyczny dla Polski do roku 2060 - Model DAS 2013)

Rys. 21. Prognozowane zużycie energii elektrycznej

(Optymalny miks energetyczny dla Polski do roku 2060 - Model DAS 2013) 
The adopted extrapolation of data for 2012-2060 is utterly arbitrary (forecast of electricity consumption for 2096 (unrealistic).

The assumed paths for GDP growth and fuel prices (Table 13) raise serious doubts.

Table 13. Assumed paths for GDP growth and fuel prices (Model DAS 2013)

Tabela 13. Założone ścieżki wzrostu PKB oraz cen paliw (Model DAS 2013)

\begin{tabular}{|c|c|c|c|c|}
\hline \multirow{2}{*}{ Years } & \multirow{2}{*}{ GDP Growth [\%] } & \multicolumn{3}{|c|}{ Fuel prices [PLN/MWh] } \\
\cline { 3 - 5 } & & Gas & Coal & Nuclear fuel \\
\hline $2013-2020$ & $1.3-3.3$ & $194.5-214.7$ & $126.8-127.6$ & $50.7-50.9$ \\
\hline $2020-2030$ & $3.3-2.7$ & $214.7-225.1$ & $127.6-125.5$ & $50.9-51.8$ \\
\hline $2030-2040$ & $2.7-2.1$ & $225.1-236.2$ & $125.5-126.1$ & $51.8-53.2$ \\
\hline $2040-2050$ & $2.1-1.2$ & $236.2-249.3$ & $126.1-127.4$ & $53.2-55.0$ \\
\hline $2050-2060$ & $1.2-1.3$ & $249.3-264.8$ & $127.4-129.7$ & $55.0-57.3$ \\
\hline
\end{tabular}

\section{Conclusion}

This paper presents a selection forecast results of primary energy demand for the world and Poland. The forecasts for 2030, 2035 and 2040 are discussed herein. They show significant differences between individual forecasts with respect to actual data resulting from incorrect assumptions and methods of extrapolation.

As to the forecasts made for Poland, discrepancies in the predicted results with the actual data preclude their practical use. World forecasts are always based on the assumption of continuity of changes (passive approach) and such solutions are not justified as far as Poland is concerned. Poland faces a dilemma of making significant changes in order to increase energy security. The forecast of continuity is not acceptable for Poland because of the rather positive prognosis for shale gas in Poland (Nagy and Siemek 2011, 2012). The alternative for Poland is a significant change in the energy mix, i.e., the formulation of a new completely paradigm. A good example would be the Scandinavian countries (Finland, Sweden, Norway and Denmark) (Graabak et al. 2014; Zakeri et al. 2014) which form an independent energy zone based on the principle of maximum energy security. Similar projects are planned in the Baltic countries (Estonia, Latvia and Lithuania) (Barisa et al. 2014) (if interested, see the latest government forecasts proposals presented at the last ECOS conference 2014 in Turku, Finland (ECOS 2014).

We should be aware of the fact that Poland is surrounded by the Russian gas transmission systems: North and South Streams. They represent highly unfriendly steps to our country, 
especially given the fact that the European Union members abandoned the Nabucco pipeline project. Currently, the benefits of the previously proposed but then abandoned concept of Poland's accession to the Norwegian gas sources, are becoming more evident. The cancellation of this project is a defeat of the Polish energy policy. In the Polish energy system scenarios, two disturbing features transpire: the scenarios, developed by various institutions and presented in intervals of several years, do not contain any new ideas; they simply reproduce the old solutions and approaches whose distinguishing characteristic are meaningless and trivial statements about the need to increase energy efficiency, implement stringent methods to reduce consumption of primary and final energy, intensify the use of renewable energy sources and reduce the emissions of greenhouse gases. Moreover, the above problems become even more acute when combined with gross negligence in the development of nuclear energy presumably in anticipation of the illusory discovery of rich shale gas deposits.

To achieve flexibility in the development of the energy system, short-term forecasts should be created, for 5-7 year spans. Creating long-term scenarios, e.g. to 2060 (as previously shown) becomes a sort of scientific science fiction.

The global nature of the world's development also requires broad international cooperation. All local solutions lead to limited sovereignty. Modern forecasting methods are described as extensive and can be found in the vast subject matter literature, for example in (Craig et al. 2002; Wang and Ryan 2010; Armstrong 2001).

The forecasts discussed in this paper and their significant inconsistency with respect to actual data, do not mean that they were based on faulty methodology or wrong assumptions and input data. The inconsistencies are due to the economic situation and technology advancement of Poland. Energy was not perceived as a resource with essential values and impact on the processes of civilisation development.

The authors wish to express their appreciation for the financial support awarded by the National Centre for Research and Development (HTRPL project, contract number SP/J/1/166183/12) and partially, under the AGH number grant number 11.11.210.198

\section{Abbreviations}

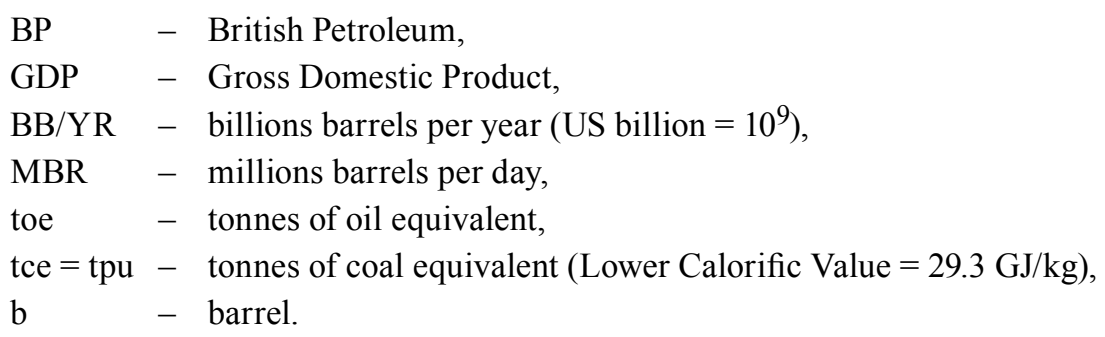




\section{REFERENCES}

A Summary of Energy, 1996. Electricity and Nuclear Data. Atomic Energy of Canada. Ottawa: AECL.

Armstrong, J.S. 2001. Principles of Forecasting - A Handbook for Researchers and Practitioners, Kluwer Academic Publishers, Springer.

Barisa et al. 2014 - Barisa, A., Blumberga, A., Blumberga, D., Rosa, M. and Kuhi-Thalfeldt, R. 2014. Modelling the Baltic Power System till 2050, Conference: 27th International Conference on Efficiency, Cost, Optimization, Simulation and Environmental Impact of Energy Systems (ECOS), 15-19 June, Turku, Finland.

BP Energy Outlook 2030, 2012 - January, [Online] Available at: www.bp.com/energyoutlook [Accessed: 15.10.2015].

BP Energy Outlook 2035, 2014 - January, [Online] Available at: www.bp.com/energyoutlook [Accessed: 15.10.2015]

BP Statistical Review of World Energy, 2014 - 63th edition, June, [Online] Available at: www.bp.com/statisticalreview [Accessed: 15.10.2015].

Collective work: Forecast - Doskonalenie energetyki cieplnej dla obniżenia energochłonności gospodarki i ochrony środowiska, 1991 - PAN, Wydział IV Nauk Technicznych, Komitet Termodynamiki i Spalania, Warsaw.

Craig et al. 2002 - Craig, P.P., Gadgil, A. and Koomey, J.G. 2002. What Can History Teach Us? A Retrospective Examination of Long - Term Energy Forecasts for the United States, Annual Review of Energy and the Environment, November, Vol. 27, pp. 83-118.

ECOS 2014 - The 27th Int. Conf. on Efficiency. Cost. Optimization. Simulation and Environmental Impact of Energy Systems. Turku. Finland. June 15-19. 2014.

Frączek et al. 2013a - Frączek P., Kaliski, M. and Siemek, P. 2013a. The Modernization of the Energy Sector in Poland vs. Poland's Energy Security, Archives of Mining Sciences vol. 58, No. 2, pp. 301 -316.

Fraczek et al. 2013b - Fraczek P., Kaliski, M. and Siemek, P. 2013b. Natural Gas and the Transformation of the Energy Sector in The Netherlands, Archives of Mining Sciences vol. 58, No. 3, pp. 789-804.

Graabak et al. 2014 - Graabak, I.,Wu, Q., Nilsson, M. and Bakken, B.H. 2014. Scenarios for a Nordic Power System without Greenhouse Gas Emissions, Conference: 27th International Conference on Efficiency, Cost, Optimization, Simulation and Environmental Impact of Energy Systems (ECOS), 15-19 June, Turku, Finland.

International Energy Outlook, 2011 - US Energy Information Administration, September, pp. 9 and 16

International Energy Outlook, 2013 - US Energy Information Administration, [Online] Available at: www.eia.gov/forecasts/ico/world.cfm (outlook to 2040) [Accessed: 15.10.2015].

Kauffmann, R.K. 1994. The effect of expected energy prices on energy demand: implications for energy conservation and carbon taxes, Resource and Energy Economics Issue, May, Vol. 16, pp. 167-188.

Kopecki, K. 1976. Man in an Energy Word (Człowiek w świecie energii), Książka i Wiedza, Warsaw (in Polish).

Kopecki, K. 1981. Jutro energetyczne Polski, Warsaw, Wiedza Powszechna.

Meadows et al. 1972 - Meadows, D.H, Meadows, D.L., Randers, J. and Behrens, III W.W. 1972. The Limits to Growth, A Potomac Associates Book, New York.

Meadows et al. 2004 - Meadows, D.H., Randers, J. and Meadows, D.L. 2004. Limits to Growth, The 30-Year Update, Celsea Green Publishing Company White River Junction VT, May.

Nagy, S. and Siemek, J. 2011. Shale gas in Europe: the state of technology - challenges and opportunities. Archives of Mining Sciences vol. 56, No. 4, pp. 727-760.

Ney, R. 1988. Polityka energetyczna kraju w zakresie możliwości zaspokajania zapotrzebowania na paliwa i energię, Conference materials. SITG, Katowice (in Polish).

Optymalny miks energetyczny dla Polski do roku 2060 - Model DAS, August 2013, Department of Strategic Analyses, Warsaw (in Polish).

PAN Forecast, Ekologiczne aspekty przetrwania energii, 1997 - Warsaw (in Polish).

PAN Forecast, Kierunki rozwoju energetyki kompleksowej w Polsce do 2010 roku, 1994 - Warsaw (in Polish).

Polityka Energetyczna Polski do 2020 roku, 1999 - Ministry of Economy (in Polish).

Polityka Energetyczna Polski do 2025 roku-założenia. 2004 - Group for Energy Policy, MEL, Katowice (in Polish).

Polityka Energetyczna Polski do 2030 roku. 2009 - Ministry of Economy, November (in Polish).

Ross, D. 1986. Learning about Energy, New York: Plenum Press, pp. 119, (Source: Economic Report of President, Energy Data from the Bureau of Mines and the Department of Energy, January). 
Siemek, J. and Nagy, S. 2012. Energy carriers use in the world: natural gas - conventional and unconventional gas resources. Archives of Mining Sciences vol. 56, No. 2, pp. 283-312.

Szurlej, A. 2013. The State Policy for Natural Gas Sector. Archives of Mining Sciences vol. 58, No. 3, pp. $925-940$.

Wang, Y. and Ryan, S.M. 2010. Effect of uncertain fuel costs on fossil fuel and electric energy flows in the US, International Journal of Energy System vol. 1, April, pp. 209-243.

Wilson, C.L. 1977. Energy: Global Prospects 1985-2000. Report of the Workshop on Alternative Energy Strategies. MIT, New York, McGraw-Hill Book Co.

World Energy Council, Energetyka Świata i Polski do 2030 roku, 2007 - Polski Komitet Światowej Rady Energetycznej (in Polish).

Zakeri et al. 2014 - Zakeri, B., Syri, S. and Rinne, S. 2014. Integration of Wind Power into Energy Systems with High Share of Nuclear Capacity - The Case of Finland 2020-2030. Conference: 27th International Conference on Efficiency, Cost, Optimization, Simulation and Environmental Impact of Energy Systems (ECOS), 15-19 June, Turku, Finland.

\title{
WIARYGODNOŚĆ DLUGOTERMINOWYCH PROGNOZ ENERGETYCZNYCH
}

\author{
Słowa kluczowe
}

prognozy energetyczne, wiarygodność

Motto

Rola prognoz nie polega na tym, żeby się spetniaty, ale aby inspirowaty debaty nad tym, dlaczego się nie spełniaja

\section{Streszczenie}

Prognozy rozwojowe różnych dziedzin stanowią istotny element w planowaniu rozwoju cywilizacyjnego społeczeństw. Trudno wyobrazić sobie podjęcie decyzji przez instytucje rządowe bez jakichkolwiek przewidywań dotyczących przyszłości. W obecnej chwili prognozy określające kierunki rozwoju systemów energetycznych odgrywają istotną rolę w zapewnieniu suwerenności ekonomicznej i politycznej krajów. Wiąże się to bezpośrednio z zamierzeniami i decyzjami w zakresie inwestycyjnym dotyczącym nowych źródeł na energię pierwotną, jak i energię finalną. Dołączyć należy wszystkie aspekty oddziaływania, zwykle niekorzystne, na środowisko naturalne. Waga problemu jest szczególnie wyraźna jeżeli uwzględni się oczywistą zależność pomiędzy wartością GNP (Gross National Product) a zużyciem energii pierwotnej.

Niestety, wszelkiego rodzaju prognozowanie, jak każda ekstrapolacja, obarczone jest zawsze błędami. W wielu przypadkach wartości błędów są tak duże, że proponowane prognozy tracą sens. Przykładami są $\mathrm{m}$. in. nieudane prognozy cen ropy naftowej.

Dobrze opracowane modele prognoz rozwojowych powinny również uwzględniać potencjalne zagrożenia, które mogą wystąpić w przyszłości, wskazując sposoby obniżenia negatywnych skutków takich zmian. Przykładem może być skokowy wzrost cen ropy na rynkach światowych w wyniku działań krajów arabskich w 1972 roku. 
Niebezpieczne sytuacje wynikają również w przypadkach, gdy kraje importujące nośniki energii pierwotnej ograniczają się do jednego kierunku nie rozwijając systemów dywersyfikacji. Taka sytuacja jest charakterystyczna dla Polski w zakresie importu gazu naturalnego i ropy.

W artykule omówiono wybrane elementy tworzenia wiarygodnych prognoz energetycznych. Przedstawiono historię prognoz energetycznych dla Polski.

THE RELIABILITY OF LONG - TERM ENERGY FORECASTS

\author{
Keywords \\ energy forecasts, reliability \\ Motto \\ The role of predictions is not about becoming real but about inspiring \\ debates about why they have not come true"
}

\title{
Absrtact
}

The paper demonstrates that the possibilities of producing reliable long-term energy forecast are limited. Global economic growth is so dynamic that the changes resulting from scientific and technological progress, which we experience, do not allow for the identification of goals over longer time intervals. For this reason, forecasting up to 2035, 2040, 2060 is devoid of its fundamental value, which is the reliability of results obtained. Are predictions to be conservative (this applies to richer countries) or are they to produce a paradigm shift by, for example, strongly imposing the requirement of increasing energy security, which is important for our country? In light of the broadness of the issues, this paper is limited to considerations relating to forecasting the primary energy demand. Detailed examples are presented for the Polish energy system. 
